\title{
Effects of Low Charge and Environmental Conditions on Diesel Generators Operation
}

\author{
Mohamad Issa ${ }^{1, *(\mathbb{D}}$, Hussein Ibrahim ${ }^{2}$, Hatem Hosni ${ }^{3}$, Adrian Ilinca ${ }^{4}\left(\mathbb{D}\right.$ and Miloud Rezkallah ${ }^{2}$ \\ 1 Institut Maritime du Québec à Rimouski, Rimouski, QC G5L 4B4, Canada \\ 2 Institut Technologique de Maintenance Industrielle, Sept-Îles, QC G4R 5B7, Canada; \\ Hussein.Ibrahim@itmi.ca (H.I.); miloud.rezkallah@itmi.ca (M.R.) \\ 3 Laboraotire de Recherche en Énergie Éolienne (LREE), Rimouski, QC G5L 3A1, Canada; \\ Hatem.Hosni@uqar.ca \\ 4 Département de Mathématiques, Université du Québec à Rimouski, Rimouski, QC G5L 3A1, Canada; \\ Adrian_Ilinca@uqar.ca \\ * Correspondence: missa@imq.qc.ca
}

Received: 26 August 2020; Accepted: 19 October 2020; Published: 21 October 2020

\begin{abstract}
In the context of electricity production in remote areas, the use of diesel generators, either alone or in hybridization with renewable energy sources, faces many technical problems. Indeed, the electrical instability that often characterizes the isolated networks, due to the fluctuating character of renewable resources and the high variability in the load profile, leads to the operation of the diesel generator in transient dynamic conditions, at low loads or outside prescribed environmental conditions. Furthermore, the extended operation of the diesel generator at low charge results in the condensation of combustion residues on the engine cylinder walls, which, after a certain time, increases friction, reduces the efficiency and increases fuel consumption. One way to solve this problem and to eliminate these deposits is to operate the engine at a higher speed until the operating temperature is reached. This paper explores the impact of the wind turbine penetration rate for hybrid wind-diesel systems and the effects of cold temperatures, high altitude, and other environmental operation conditions on diesel generators' performances. We outlines the impacts of low load and environmental conditions such as ambient temperature, humidity, moisture, abrasive dust, cold and corrosive environments on the operation of modern diesel generators. The problem has been approached by examining the existing literature, researching damage cases, analyzing existing data, and assessing industrial experiences.
\end{abstract}

Keywords: diesel generator; low load; optimization; combustion engine; stand-alone power-generating; cylinder bore polishing; wet stacking; cylinder glazing; hybrid wind-diesel system

\section{Introduction}

Hybrid power systems are commonly used in stand-alone renewable energy-generating grids. To ensure high electricity quality and, above all, supply continuity and reliability, energy storage systems and stand-alone power generation systems such as diesel generators (DGs) are used. Applying DGs in hybrid systems along with other electric power sources also causes the diesel engine to operate at a reduced load for long periods [1]. This leads to "wet stacking," which increases the commonly known cost of engine exploitation and unfavorable environmental phenomena [2]. Furthermore, operating a DG set at a load level less than $30 \%$ of maximum output is the key trigger behind the polishing and glazing phenomena of cylinders [3-5]. These problems are appear in underloaded generator sets in stand-alone hybrid ship grids as well. When attempting to ensure safety during maneuvers and while navigating "difficult" areas (river, canal, straits, lakes, etc.), the simultaneous operation of stand-alone 
power generation systems is necessary to ensure continuous power supply, irrespective of the power demand. Under these conditions, DG-driven engines are frequently underloaded (20-30\% of maximal power) [6]. In these circumstances, the fuel is not fully burned, which causes exploitative problems in the DG sets' diesel drive engines.

The overflow of the air supplied for burning occurs when the diesel engine is underloaded (the air-to-fuel ratio will exceed 500:1). Not all the fuel injected will be burned, and this can condense, forming carbon deposits on the engine elements' surface [7]. Partial oil-burning results in a higher relative $\mathrm{CO}_{2}$ coefficient and emissions of greenhouse gases (GHG). For example, $\mathrm{HC}, \mathrm{CO}$, and NOx $(\mathrm{g} / \mathrm{kWh})$ emissions are two to three times higher at $25 \%$ engine load than at $75 \%$ load [8]. Table 1 shows the effects of low load operation and describes the impacts on a diesel generator set's performance.

Table 1. Overview of the various effects that occur after low load diesel generator operation.

\begin{tabular}{|c|c|c|c|}
\hline Definition & Signs of Appearance & Causes/Consequences & Illustration \\
\hline Wet stacking & $\begin{array}{l}\text { Presence of a black ooze } \\
\text { around the exhaust } \\
\text { manifold, piping, } \\
\text { and turbocharger, if fitted }\end{array}$ & $\begin{array}{l}\text { Cold weather running, } \\
\text { low load or other causes that } \\
\text { prevent the engine from } \\
\text { reaching proper operating } \\
\text { temperature }\end{array}$ & \\
\hline Polishing cylinder & $\begin{array}{l}\text { The physical phenomenon } \\
\text { which results in the } \\
\text { formation of a mirror-like } \\
\text { area on the cylinder's inner } \\
\text { surface }\end{array}$ & $\begin{array}{l}\text { Increased lubricating oil } \\
\text { consumption and loss of } \\
\text { power }\end{array}$ & \\
\hline Glazing cylinder & $\begin{array}{l}\text { The chemical phenomenon, } \\
\text { creating a coating on pistons } \\
\text { and liners with a certain } \\
\text { coloration }\end{array}$ & $\begin{array}{l}\text { Increased lubricating oil } \\
\text { consumption, loss of power } \\
\text { and engine smoke }\end{array}$ & \\
\hline
\end{tabular}

The use of a load bank is a common way of reducing these disadvantageous impacts in the industry, especially in the USA [9]. Most frequently, this is an automatically operated resistor that loads the generator unit of the DG, which transforms electrical energy into heat energy. Improving the operating condition of the diesel engine eliminates the effects of the low load operation, but at the cost of increased fuel consumption. On the other hand, a combination of small modern diesel-generating sets whose combined power output is equal to a single large diesel generator can prevent the large engine from operating under a partial load [10].

Generator-configured diesel engines are usually designed for medium to high engine load operations. The low-charge operations will increase operational problems and hence the level of damage [11]. It is also expected that the new exhaust pollution regulations worsen the negative effects of low-charge operations [12].

This article investigates the impacts of low load operations on modern diesel-generating sets in hybrid configurations. It introduces mechanical and natural phenomena that are at the origin of the degradation of diesel-generating sets' performance in off-grid applications. The structure of the present article is as follows. In Section 2, we explain how a DG can be subjected to a low load when combined with a renewable energy source that provide the electrification of an isolated site. In Section 3 , 
we present low and transient load operations and their impacts on modern diesel-generating sets, while in Section 4, we discuss the environmental operation conditions that are at the origin of the deterioration of a diesel-generating set's performance. Section 5 provides a conclusion, whilst Section 6 a perspective for future work.

\section{The Use of Hybrid Systems Combining Renewable Sources with Diesel Generators}

By integrating renewable energy with diesel generators, the use of hybrid systems makes it possible to minimize overall fuel consumption, resulting in an environmental and economic benefit. Wind energy has witnessed the fastest growing trend of all renewable energies, at more than $30 \%$ annually over the last 10 years. [13,14]. Low penetration WDS (wind-diesel systems) have already been introduced in Yukon [15], Nunavut [16] and Alaska [17] in the Nordic communities. By low penetration systems, we mean that the overall instantaneous wind power is $20-35 \%$ of the diesel rated power and that the total wind energy does not exceed $10-15 \%$ of the total consumption $[18,19]$. Generally, the WDS uses an existing diesel power plant and an additional wind farm containing a single model turbine [20]. To these two principal elements are added logic and the components necessary to the hybrid exploitation of the system, including secondary loads for smoothing, a regulator and automated command. The rise in the amount of wind penetration enables better fuel reduction. However, from this viewpoint, the first challenge emerges from the operational constraints of diesel engines. In order to respond to a sudden reduction in wind power, it is important to maintain the engines on stand-by at more than $30 \%$ of their nominal power output, above a certain penetration level. This limits the penetration of wind energy to a degree of too poor, and the wind turbines act merely as a negative charge for the network. Wind diesel systems with high penetration without storage are those wherein the output of wind power exceeds the charge for long periods of time. [21]. This enables the diesel engines to stop completely during those times, resulting in a major reduction in fuel consumption. This design is, in the meantime, subject to complex technical problems [22,23]. As a result of these issues, only projects of this kind are currently operational in Alaska, i.e., without energy storage. The diesel engine must also be kept on stand-by during such times as when the excess of wind energy over the charge is reduced so that it can respond quickly to a reduction in wind speed (reduction of engine startup and heating time). This is an important cause of over-consumption and underperformance operation because the engine could turn for tens or up to $50 \mathrm{~h}$ without supplying any useful energy, and operate inefficiently (see Figure 1). In the long term and with similar repetitive conditions, the lifetime of the DG becomes premature.

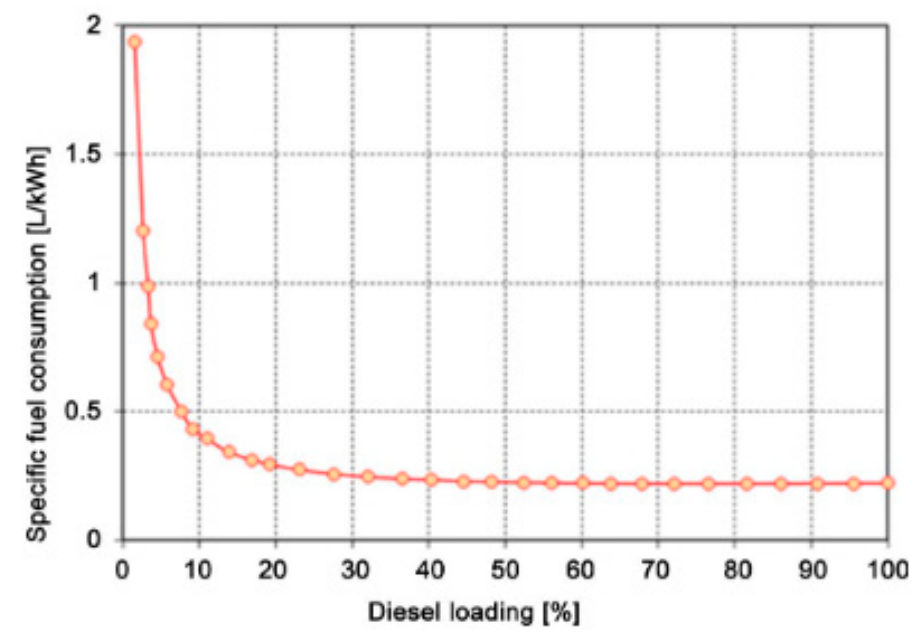

Figure 1. Variation of diesel fuel consumption per $\mathrm{kWh}$ for a $400 \mathrm{~kW}$ DG according to the applied load [24]. 
Figure 2 shows a high penetration WDS [25] operating example for a $480 \mathrm{~kW}$ user load. Fuel savings start when the wind speed is higher than $4 \mathrm{~m} / \mathrm{s}$. Wind power is adequate to cover customer demand without the input of diesel engines when wind velocity exceeds $9 \mathrm{~m} / \mathrm{s}$. However, when a margin of $30 \%$ is reached between customer demand and available wind power, diesel engines are stopped. Surplus wind power is lost at wind speeds greater than $9 \mathrm{~m} / \mathrm{s}$. The combination of a storage portion with a high WDS penetration enables the excess wind energy that frequently occurs and is otherwise dissipated to be stored, then used later when necessary. Therefore, the request for fuel energy is lowered. The use of energy storage with WDS leads to more savings and less environmental impact by increasing the penetration rate of wind energy (i.e., the percentage of wind energy as the overall energy consumption on an annual basis) by assuming optimum exploitation conditions [26].

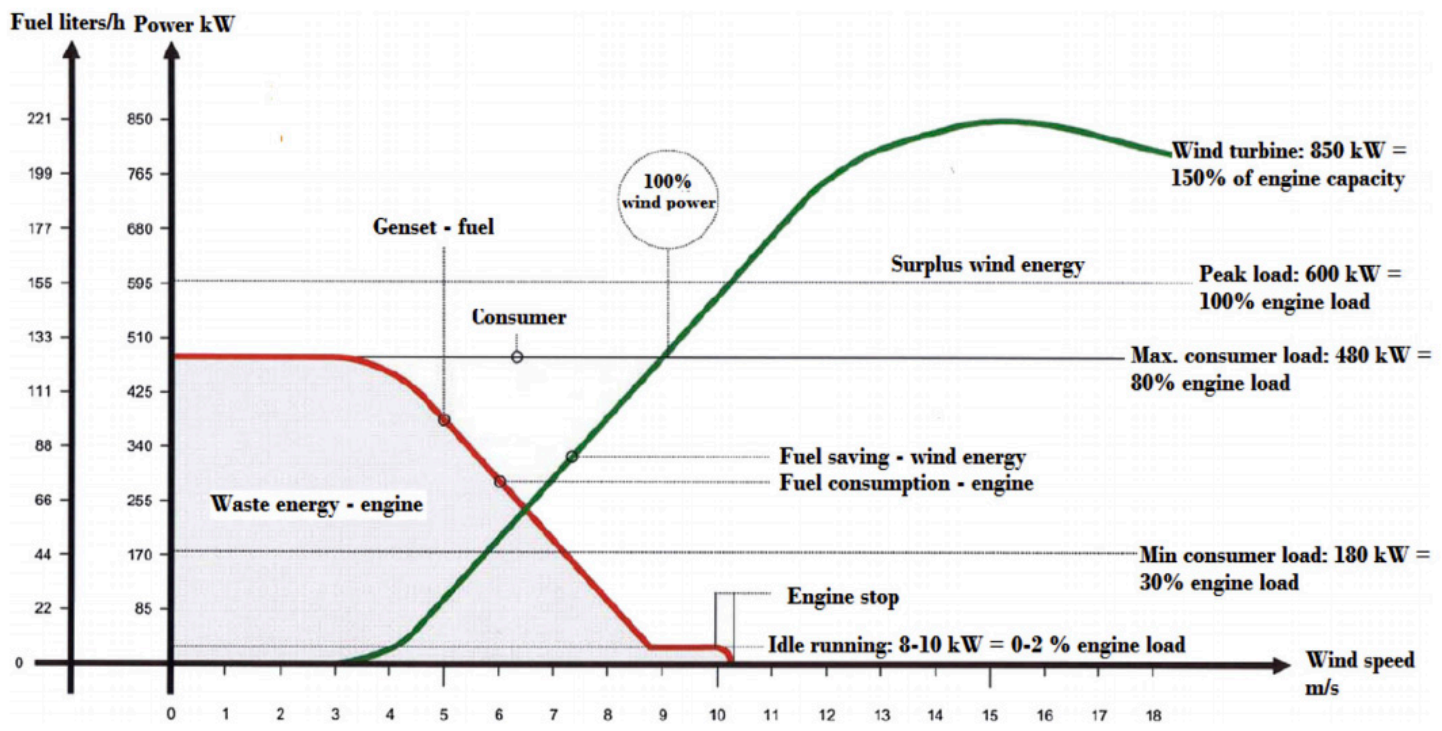

Figure 2. Example of power contribution and fuel consumption of a high penetration wind-diesel generator.

\section{Low Load Operations}

Asco power technologies define the low load operations of diesel engines as engine operations at loads below the maximum continuous rating of 30\% [27], while DNV GL below the continuous rating of $40 \%$ [12]. Engine loads in the $40-80 \%$ range are classified as regular operation. Definitions of the complete load spectrum appear in Table 2.

Table 2. Load levels in the percentage of continuous maximum rating.

\begin{tabular}{cc}
\hline Applied Load & Description \\
\hline $0-25 \%$ & Extreme low load \\
$25-40 \%$ & Low load \\
$40-80 \%$ & Regular generator operation load \\
$80-90 \%$ & High load \\
$90-100 \%$ & Extreme high load \\
\hline
\end{tabular}

From an engine builder point of view, brief periods of low load operation are appropriate, because the engine periodically operates at full load. In this case, if properly maintained, diesel generator sets can operate for long periods with no harmful effects under light loads. After the operation at low load levels, each impacted generator set will work under a higher load to increase the temperature and pressure in the cylinder, which cleans the combustion chamber deposits. Moreover, if low load operation is likely to occur frequently, a more robust maintenance program will help to ensure that there is no excessive wear of components and reduce the risk of unplanned downtimes. 
For diesel generator sets, for every four hours of the extremely low load operation, Caterpillar recommends loading the generator set at a minimum of $30 \%$ load for about $30 \mathrm{~min}$. To ensure that the required exhaust temperatures are met during operation, exhaust temperature measurements should be taken at the exhaust manifold before the turbo or in the exhaust stack just after the turbo.

\subsection{Effects of Low Load Operations}

Low load diesel engine operations cause lower cylinder pressure and thus lower temperature. Low temperature can result in problems with ignition and poor combustion, causing increased soot formation and the accumulation of unburned fuel in the cylinder [28]. Low cylinder pressure, soot, and unburned fuel deteriorate the sealing capacity of the piston ring, allowing hot combustion gases, soot particles, and unburned fuel to escape through the rings of the pistons. This results in the increased use of lubricating oil and the dilution of diesel [29]. The lubricating oil's fuel dilution decreases the viscosity that could break critical film thicknesses. This may cause pistons, rings, liners, and crankcase bearings to wear prematurely $[12,29,30]$. Low load mechanisms lead to a process of deterioration, which means that diesel engines running for more extended periods at low loads may become irreversibly damaged. This is demonstrated by a case of engine damage in a generator configuration (see Table 3). The failure case presents a breakage of the engine crankcase initially caused by piston scuffing from the breakdown of the lubrication oil after prolonged low load operations. Figure $3 a$ illustrates piston scuffing, while Figure $3 b$ shows hard carbon deposits on the top land of piston number 4 [31].

Table 3. Illustration of the engine specifications.

\begin{tabular}{cc}
\hline Engine Type & Four Strokes, Tier I \\
\hline Cylinder configuration & V-engine, 16 cylinders \\
Aspiration & Turbocharged \\
Engine Output & $1690 \mathrm{~kW} / 1800 \mathrm{rpm}$ \\
Operating hours & $15,000 \mathrm{~h}$ \\
\hline
\end{tabular}

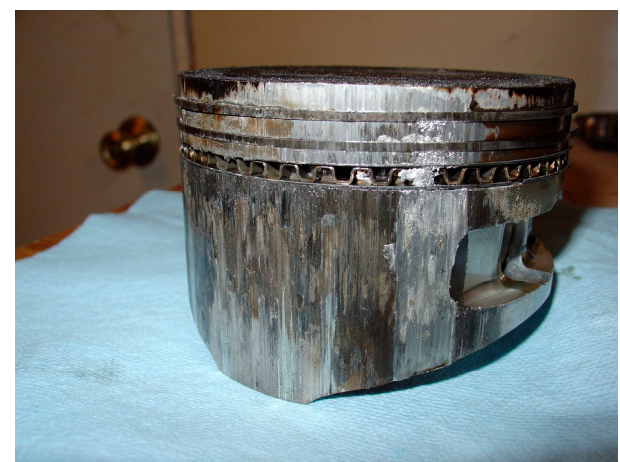

(a)

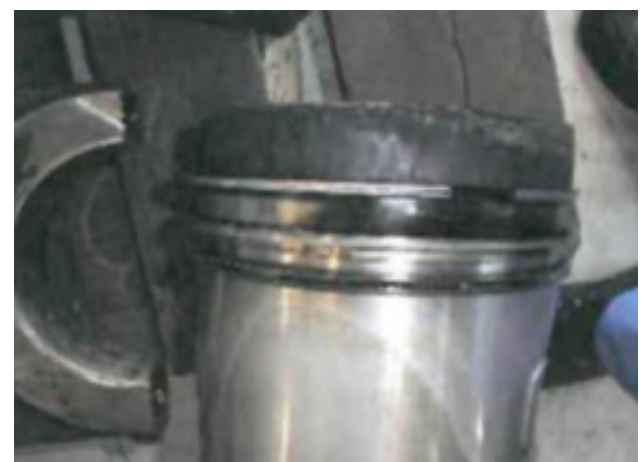

(b)

Figure 3. Piston scuffing and hard carbon deposits. In (a) piston scuffing while in (b) hard carbon deposits on the top land of piston [31].

According to W. Stachowiak and A. Batchelor [32], when there is a breakdown or lack of lubrication, scuffing does result from mechanical contact. The investigative report indicates that prolonged engine operations at low loads are the cause of piston scuffing. This conclusion is based on trends of engine load history records, and the findings of an oil analysis [31]. 


\subsection{Effects of Transient Load Operations}

Transient load operations have a detrimental effect on engine operating conditions, along with low load operations. In general, diesel engines can experience a wide range of operating conditions, which are classified as transient. The operation at transient regimes of a diesel engine operating as a generator that is part of a wind-diesel hybrid system is primarily due to sudden changes in the load or output of renewable energy sources (wind or solar photovoltaic). However, the transient load operations of marine diesel engine generator drives are due to sudden changes in power demand from the propulsion or deck equipment. Figure 4 demonstrates step by step the rise in load in a turbocharged diesel engine that is used as a generator [33]. Important steps of the load change are shown in bold print.

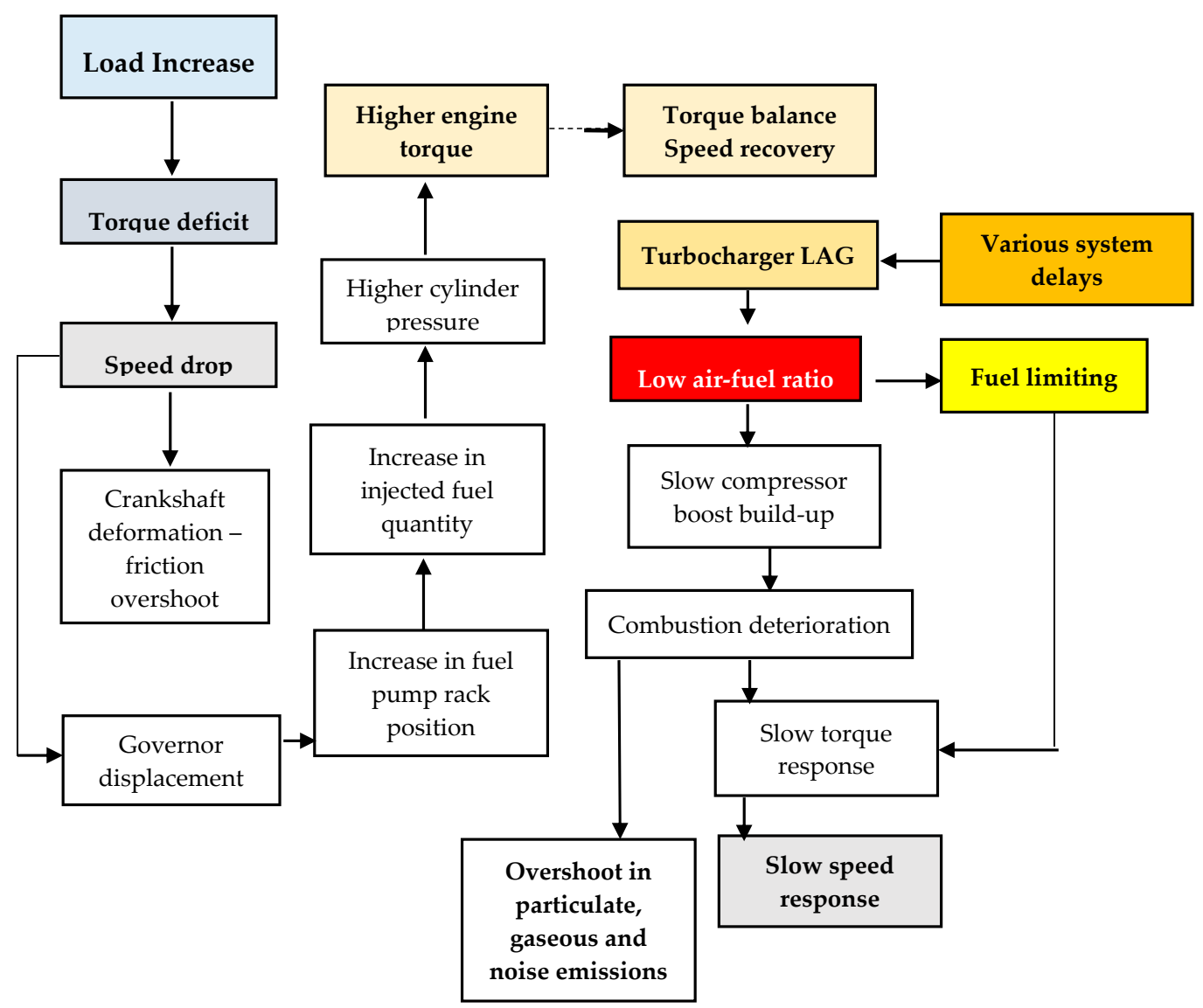

Figure 4. Impact of the abrupt load change on engine performance.

The impact of the increased load on the operation of the diesel generator, illustrated in Figure 2, can be described as follows: initially, the engine torque and load are equal, and the air/fuel ratio is relatively high. When the load increases, the engine suffers a net torque loss because the engine torque cannot respond instantly to the increased load variation. The loss of torque causes the engine speed to decrease, and the governor increases the amount of fuel to adjust the speed. As a result, the air/fuel ratio decreases due to insufficient air mass flow, which is caused by a response delay of the turbocharger. The turbocharger delay is caused by the fact that the increase in exhaust power is not able to increase the instantaneous turbine power due to the inertia of the turbocharger. During this short delay, the engine runs like a naturally aspirated engine, and the air/fuel ratio can be much lower. These low values can lead to intolerable smoke emissions and the formation of soot. A low air/fuel ratio increases the temperature in the combustion chamber, which can lead to the formation of large amounts of NOx. Mechanical stresses due to deceleration act on the crankshaft (where the load torque 
is greater than the engine torque). The highest deceleration occurs during the first cycles when the torque difference between engine and load is at its maximum.

\section{Environmental Operation Conditions Effect on Diesel Generator Performance}

Structural and thermal constraints mainly limit engine power. These constraints include maximum cylinder pressure during the combustion phase, turbocharger speed, and exhaust gas temperature. However, these constraints must take into consideration the limitations of certain environmental factors, which have an impact on the performance of the engine and generator parts, and consequently, on the diesel generator. These factors include altitude, ambient temperature, corrosive atmosphere, humidity, and dust [34]. The optimal performances of diesel generators require operation within certain limits for these variables. Indeed, when an engine exceeds the maximum altitude or ambient temperature, a decrease in engine performance is noticed.

\subsection{Effect of Ambient Air Temperature and Humidity}

Low load operation contributes to reduced efficiency. Furthermore, the maximum power output is limited by the speed of operation. The maximum power will be greater at high speeds ( $3600 \mathrm{rpm}$ for example), but the percentage of the output load will be greater.

However, if it is lower, this will reduce the effectiveness. The maximum power will be lower at low operating speeds (1800 RPM), improving the load 's performance, but the output power will be reduced. The performance of the system could be improved by allowing the speed to differ with respect to the specified load or by increasing the load to match the maximum output at the specified speed. However, extremely high or low temperatures reduce diesel generator efficiency. For example, when the intake air temperature is above $40^{\circ} \mathrm{C}\left(104^{\circ} \mathrm{F}\right)$, the power generated by a diesel generator will begin to decrease. On the other hand, due to the relatively high density of cold air, air entering the engine cylinders at low temperatures will lead to an increase in power output [35]. However, it is also possible to observe two other anomalies related to the low air temperature operation of the diesel generator: the cold start and the formation of gels and emulsions in the blow-by circuit, as explained later.

In [36], Rakopolous has studied the relationship between ambient air temperature, humidity ratio, efficiency and the specific fuel consumption (SFC) of high speed DGs in Greece. Figure 4 shows the variation in the brake mean effective pressure (BMEP) along with the fuel to air equivalence ratio $(\Phi)$ for different ambient temperatures and humidity ratio $(\mathrm{w})$ values.

According to Figure 5, it is evident that for a certain equivalence ratio, the low ambient temperature issue often generates a high BMEP inside the cylinders. Similarly, the lower humidity issue still increases the BMEP to a certain equivalence ratio for the two temperatures involved.

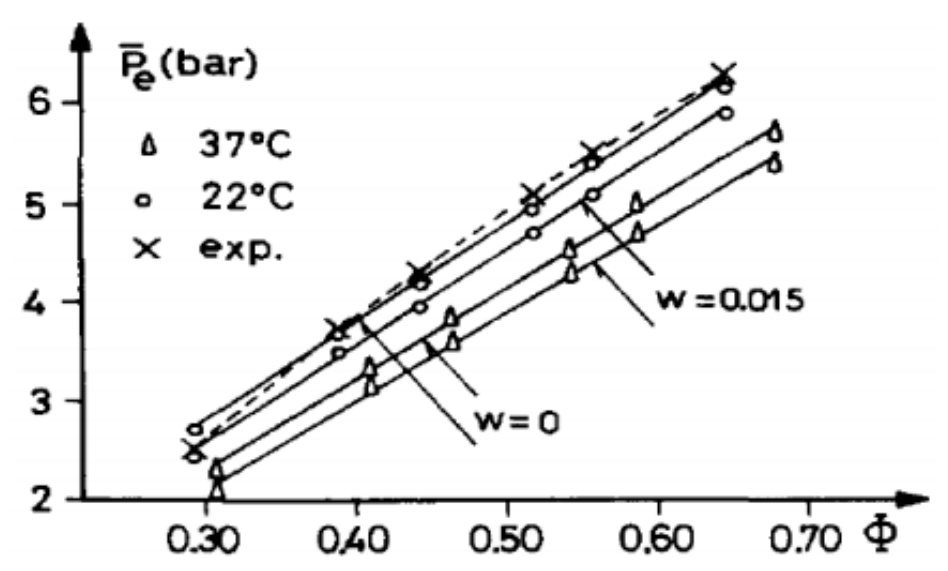

Figure 5. BMEP variation vs. air equivalence ratio $(\Phi)$ projected with ambient temperatures and humidity ratio $(\mathrm{w})$. 
As per Rakopolous' analysis, the variation in combustion efficiency along with the humidity ratio $(w)$ and ambient temperature is shown in Figure 6. The combustion efficiency is often greater at the lowest temperature and lowest humidity ratio scenario for a certain fuel to air equivalence ratio $(\Phi)$.

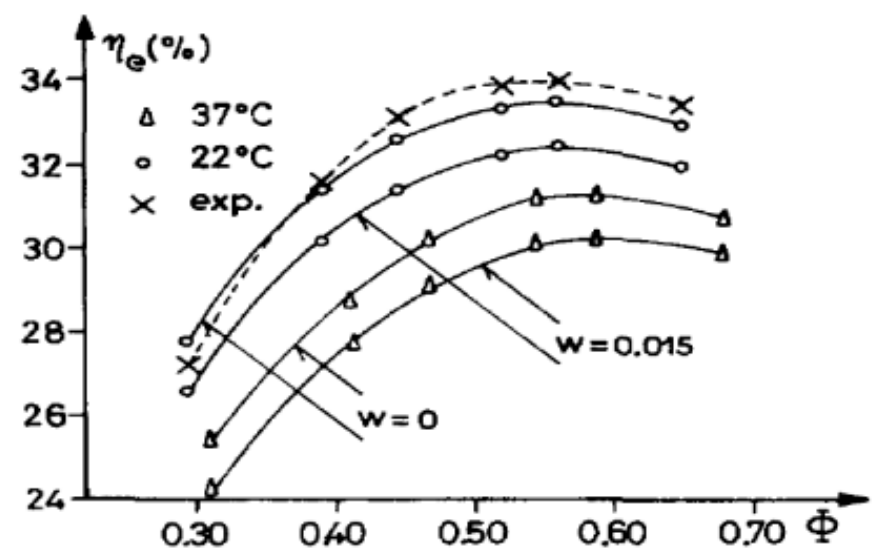

Figure 6. Variation of efficiency vs. fuel to air ratio equivalence $(\Phi)$ plotted with different temperatures and humidity ratios $(\mathrm{w})$.

On the other hand, DGs are known to run at varying ambient air temperatures. This variance in temperature would directly affect the diesel engine's efficiency. For example, when the engine consumes hot air, there are less air molecules to burn along with the fuel [37,38]. This causes unburnt fuel to exit the combustion chamber, resulting in less power being produced. For every $3{ }^{\circ} \mathrm{C}$ rise in air intake temperature, engine power will be reduced by $1 \%$ [38].

Furthermore, experimental work conducted by Abdullah, N.R. et al. [39] shows that fuel consumption is improved with a decrease in air intake temperature regardless of engine speed. The lowest value of brake specific fuel consumption occurred at an air intake temperature of $20^{\circ} \mathrm{C}$, compared to $30^{\circ} \mathrm{C}$, which was $4 \%$ lower at the same engine speed of $1500 \mathrm{rpm}$.

\subsection{Cold Start Effect}

The starting of a diesel generator is considered cold until the engine and fluids have reached a normal operating temperature. At temperatures below $60^{\circ} \mathrm{C}$, a change in the injection timing and amount of fuel injected optimizes combustion stability and reduces emissions during the warm-up phase of the engine $[35,40]$. Temperatures below $0{ }^{\circ} \mathrm{C}$ need more drastic changes, especially regarding the type of oil used (less viscous oil is more suitable for cold conditions). At low ambient temperatures, the starting quality will deteriorate significantly to the point where the engine startup is no longer possible. Figure 7 shows the most important engine parameters affecting the efficiency of cold start and the relationships between those parameters.

Furthermore, low temperatures reduce battery capacity and increase both engine friction and oil viscosity. This leads to a high torque demand from the motor at low speeds. Thus, the power produced by a diesel engine operating in extreme temperatures or at sites at non-optimal altitudes will not be sufficient to increase the engine speed to a level above the one corresponding to the low speed operation. This results in an increased starting time [35]. It is essential to mention that during startup and idling, the heat losses are significant, resulting in a reduced end of compression temperature and pressure peak. The other consequences of this type of operation are increases in fuel injection delays (physical delay) and combustion delays (chemical delay). The combination of these consequences will lead to a degradation in the self-ignition speed and a complete diesel engine malfunction $[35,40]$. Figure 8 summarizes the three main main effects of cold start on the engine:

- Lubricant that is too viscous leads to more significant friction loss; 
- Too cold engine cylinder walls lead to a deterioration in combustion quality and increased piston/cylinder friction (mechanical performance degradation);

- The catalytic converter is too cold to control the emissions.

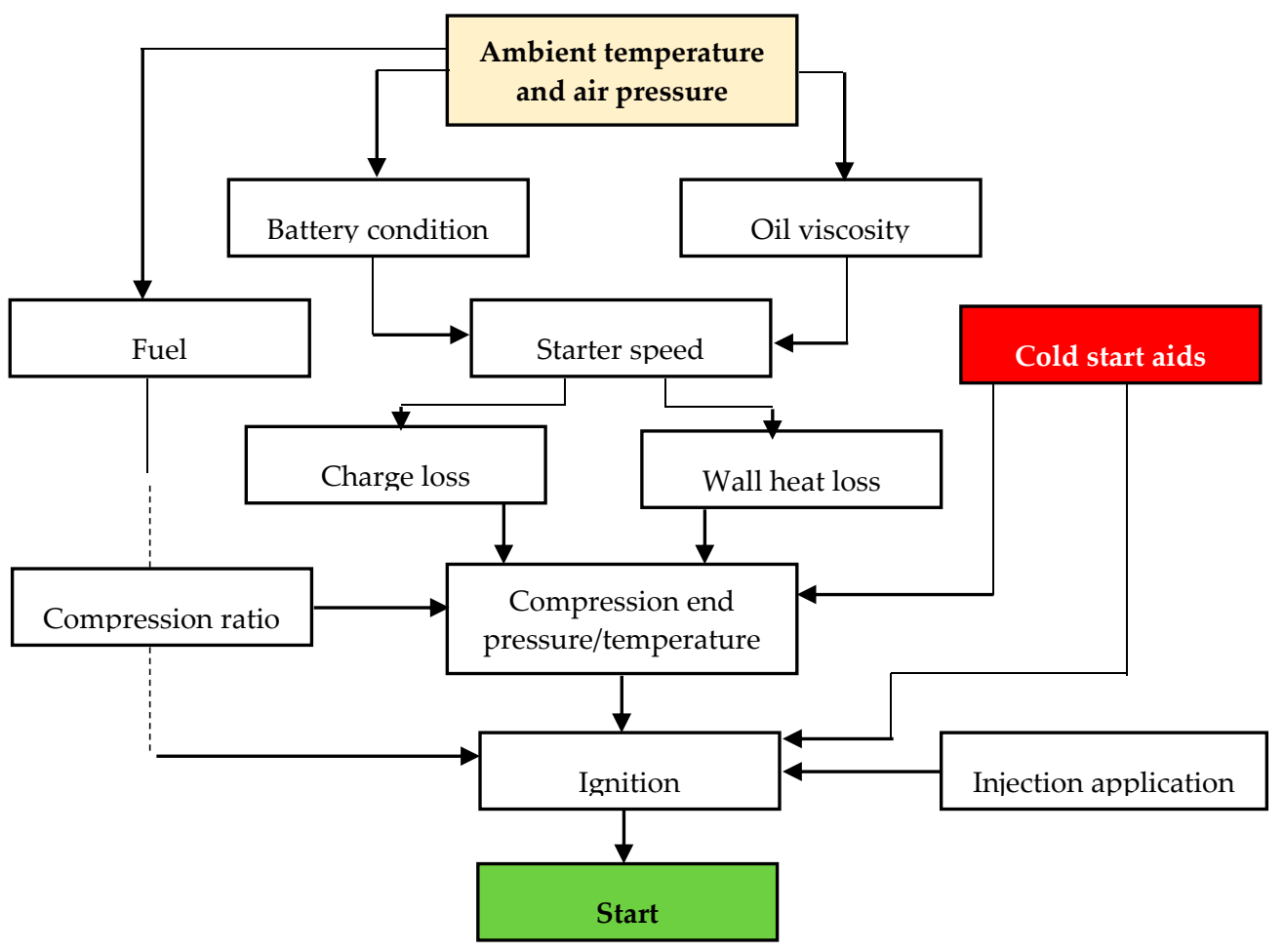

Figure 7. Influence of different parameters on cold startup.

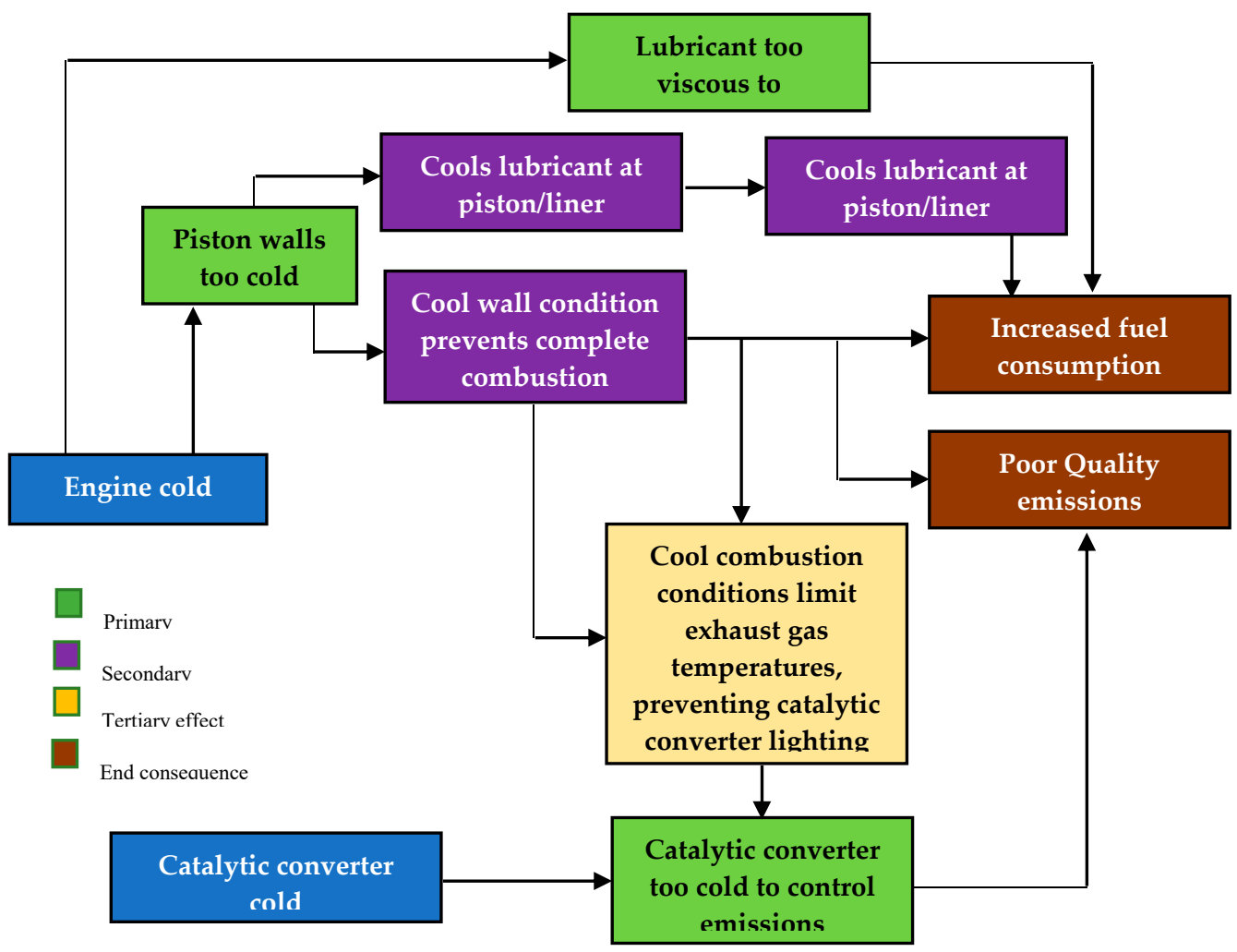

Figure 8. Diagram of causes of cold start inefficiency. 


\subsection{Freezing and Emulsion Formation in the Blow-By Circuit}

Figure 9 shows a simplified diagram of a cylinder in a diesel engine. In the upper part, the combustion chamber is separated from the low-pressure crankcase by the pistons. During an engine cycle, due to the defect of the sealing rings, the pressure in the combustion chamber causes a gas leakage towards the engine's bottom. This is called "crankcase gas" or "blow-by gas." As required by regulations, blow-by gas should not be released into the atmosphere because of pollution risks $[41,42]$. Thus, the gas is recycled to the intake circuit through pipes and a settling system called the blow-by circuit.

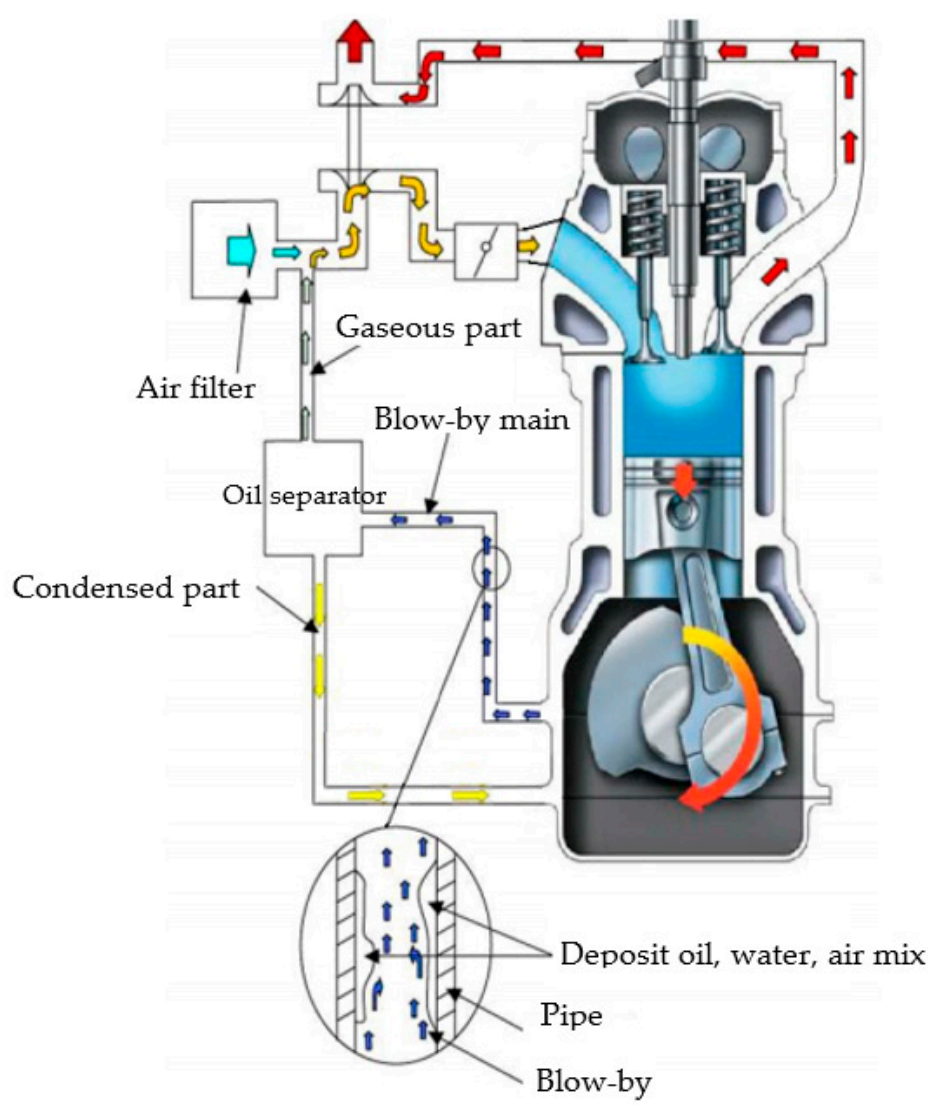

Figure 9. Blow-by gas flow diagram inside the engine.

In cold countries, such as Canada, low ambient temperatures (below $0{ }^{\circ} \mathrm{C}$ ) can last for several months, resulting in the appearance of frost and blow-by emulsion [43]. The operation conditions accentuate the phenomena in the regions concerned; among other things, the location of the diesel engine in the open air in cold weather conditions, and operation for a short period and at low load, both mean that the engine does not have enough time to warm up.

Freezing and blow-by emulsion can cause significant problems in the operation of the diesel engine. By accumulating at various points in the blow-by system, the gel or emulsion can cause a blockage in the blow-by system, causing the crankcase to build up pressure and oil to be ejected. In the long term, this can damage the engine or start a fire if the oil spills over a hot part of the engine.

\subsection{Influence of Altitude on Diesel Engine Performance}

Atmospheric pressure and the drop in air density with altitude both affect engine performance [44]. For example, the lower air density in the cylinder causes a smaller droplet size, which leads to a reduction in coalescence $[45,46]$. This lower coalescence reduces the impingement of jet-to-wall. Lower density decreases the spray angle resulting in increased spray penetration [47]. Therefore, 
the combustion initiation is advanced at a higher altitude, causing increased maximum in-cylinder pressure and mechanical loads on the cylinder walls [48]. Another consequence of the lower density is the increase in the lift-off, which increases the penetration of fresh air into the jet and decreases initial soot formation $[49,50]$. However, the lower soot oxidation rate induced by the lower density in the combustion chamber increases the soot production at the end of the combustion cycle globally.

In [51], the pressure in the cylinder decreased as the altitude increased from 0 to $3000 \mathrm{~m}$, and the number of speed-up cycles increased during the acceleration time. As the altitude increased to $4500 \mathrm{~m}$, a misfire occurred. The author confirms that the misfire at the high of $4500 \mathrm{~m}$ altitude was caused by the ignition delay, which was mainly controlled by a chemical reaction at the cold start.

Furthermore, in [52], the brake thermal efficiency of four altitudes, including $0 \mathrm{~m}, 1600 \mathrm{~m}, 3300 \mathrm{~m}$ and $4500 \mathrm{~m}$, consistently decreased with the rising of altitude. This showed that the delayed start of combustion, the reduced ratio of factual expansion, the decreased specific heat ratio of the mixture of airfuel, the aggravated inefficiency of the turbocharger, the deformed fuel spray and the increased heat transfer led to the degradation of the thermal efficiency of the brake when the engine was running at high altitudes. However, Perez and Boehman [53], found that power output depended primarly on engine load, and was not improved by the use of oxygen-enriched air. Fuel injection timing is the most important factor in decreasing brake-specific fuel consumption (BSFC) by $55 \%$ at the middle injection timing, while a more modest effect was observed for oxygen enrichment, with a reduction of about $40 \%$ for an oxygen volume fraction of $22 \%$. The use of oxygen-enriched air prevented the deterioration in BSFC when increasing simulated altitude, which did not occur with standard air. A similar effect was observed on fuel conversion efficiency when using oxygen-enriched air. On the other hand, He et al. [54] showed that the effect of high altitudes on the emission of NOx varies according to the types of engines and working conditions. The emissions of particle numbers at $1000 \mathrm{~m}$ are 1.6 to 4.2 times the levels at low altitudes. The pattern of the distribution of the particle size at $1000 \mathrm{~m}$ is close to that of the mono-modal lognormal distribution with a geometric mean diameter of about $0.1 \mu \mathrm{m}$ at sea level. The peak number of particle concentrations, however, is greater, and the exhausted particles are smaller at high altitudes.

\subsection{Corrosive Environments}

The corrosion of metals in a marine environment can cause huge economic loss. The presence of salt will corrode electrical parts such as rectifiers and windings. This can lead to isolation resistance degradation and contact resistance increase [55]. Insulation resistance is one of the critical readings of marine electrical equipment systems, and serves as the best guide to indicate the health of the electrical machinery. With time, the insulation begins to age, and this causes deterioration in the performance of the insulation. Harsh operating environments, where the electrical insulation is exposed to extreme operating temperatures, moisture, and chemical contamination, as experienced on a ship, will accelerate the deterioration process [56]. It is extremely critical to always know this electrical condition of the insulation in a ship's electrical alternator at all times, so as to avoid any accident such as electrical shock, fire, or short circuit. Salt also corrodes metallic components such as the bearings and the shaft, which reduce mechanical strength and capability [57]. Light corrosion along the outside of the fitted bearing does not have an adverse effect. Rust presence in the interior of the bearing is, however, critical in many respects. On rolling surfaces, localized pitting corrosion produces stress peaks during overrolling, which can lead to premature fatigue. As in the case of false brinelling, rust particles have an abrasive effect and lead to wear.

\subsection{Moisture}

Condensation resulting from moisture is a problem for all diesel generators unless they are completely enclosed or kept warm enough during shutdown periods. When any warm dry generator is shut down, it draws in fresh cool air, wich always contains some moisture, even in hot, dry weather [58]. If the generator is operated continuously, or frequently, the insulation remains sufficiently dried out 
to prevent insulation failure. However, if the generator stands idle for long periods, especially in an unheated area during humid weather, the trapped moisture may accumulate until the insulation becomes a partial conductor of electricity. If normal voltage is then applied, the insulating material may fail and the generator must then be rewound before it can be operated again.

On the other hand, the moisture has also a significant impact on the electrical arcing and wear of the generator brushes. To keep the wear and electrical arcing down, the brass or bronze brushes inside the generator are lubricated. This lubrication wears away when they get wet. The brushes are then weakened and worn out by the electric arc. Furthermore, too much moisture in unseen places can cause rust. This material would then produce non-conductive films that cause arcing, rapid brush and commutator, or slip ring wear when applied to the commutator or slip ring [59]. Low humidity can result in rapid brush wear due to the mechanical friction caused by an inability to produce a film, as seen in northern and desert climates, and in freezer and high-altitude applications.

Rising temperatures and the circulation of generator cooling air with sufficient, and even operating, load can prevent this condensation. Heaters may help to raise the temperature to $5{ }^{\circ} \mathrm{C}$ above ambient temperature to prevent condensation in areas of high humidity $[60,61]$.

\subsection{Abrasive Dust}

Dust and other particles constitute another hazard, as they cause the mechanical abrasion of the varnish, which will gradually lead to a deterioration in its performance. Since air circulation is used for cooling inside the alternator, the presence of particles in the environment is particularly harmful [62].

Abrasive dust absorbed through the cooling fan can damage a diesel generator. These specks of dust include iron dust, carbon dust, sand, graphite powder, coke dust, wood fiber, and quarry dust. When these foreign particles get into the generator, they act like sandpaper rubbing against the insulation. These abrasives can cause a short circuit in the electrical generator. An accumulation of these materials will act as insulation or as a moisture trap. Furthermore, they will cause significantly higher winding operating temperatures if these materials reach the generator cooling circuits, which increases the rate of thermal ageing in order to decrease the insulation life. These materials join the generator endwindings and cool air ducts in engines with open-type enclosures to clog them up. This type of contamination is accelerated if it occurs in combination with that from oil, grease, or moisture. Furthermore, the reduction in winding cooling that results from contamination will increase the generator's $I^{2} \mathrm{R}$ losses to reduce its efficiency [63]. Filters that fit over the air intake or vent opening unit can prevent these problems. When using filters, they must be regularly changed so that they do not impede the airflow. The use of an air filter may, in turn, reduce output power due to the temperature increase resulting from a lower cooling airflow.

\section{Conclusions}

This article investigates the impacts of low load operation on diesel generators. We studied the conditions resulting in performance deterioration for diesel generators. Operational and environmental conditions affect these performances. The main conclusions are as follows.

Low load operations of diesel engines occur when the loads are below $30 \%$ of the maximum power. Low load diesel engine operations cause lower cylinder pressures and thus lower temperatures. Lower temperatures can lead to problems with ignition and incomplete combustion, resulting in increased soot formation and the accumulation of unburned fuel inside the cylinder. The effectiveness of sealing the piston ring depends on the gas pressure in the combustion chamber for proper functioning. Low cylinder pressure and piston ring glazing deteriorate the sealing effectiveness and aggravate the initially low cylinder pressure. Deteriorated piston rings allow hot combustion gases and particles to blow past the piston rings and ignite the lubricating oil film, from which liner glazing will result. Hard carbon particles arising from incomplete combustion polish and smooth the liner.

The engine damage presented in this article involves the breakage of the engine crankcase originally caused by piston scuffing. The scuffing results from mechanical contact when a failure or 
lack of lubrication occurs. Excessive low load operations cause the contamination of the lubrication oil, which eventually leads to a breakdown of the oil film.

Environmental conditions also affect diesel generator performances. Cold start, ambient temperature, altitude, corrosive environment, dust and humidity can negatively affect these performances.

The impacts of low charge operations are of concern if precautions are not taken, according to the engine manufacturers. Diesel engines operating at low loads must be brought up to high loads (at least $40-50 \%$ of full power) regularly to avoid operational problems. Increased engine loads raise the pressure and temperature, scrap the liner lacquering, and burn the soot deposits and unburned coal. These guidelines are included in the engine user manuals, without exception.

\section{Suggestions for Further Work}

The following elements would be worthy of further investigation:

Develop a test bench to verify the possibility of automatically detecting an underperformance in generator activity (light load: $<30 \%$ ) to reduce the extended time under low load. This work would include the measurement of $\mathrm{CO}, \mathrm{CO}_{2}, \mathrm{NO}_{\mathrm{X}}, \mathrm{SO}_{\mathrm{X}}$ and $\mathrm{PM}$ parameters along with cooling temperature, and intake shouold be registered and examined when applied loads vary;

The development of an advanced underperformance detection algorithm based on artificial neural networks.

Author Contributions: Conceptualization, M.I. and H.I.; methodology, M.I.; validation, A.I., M.I. and M.R.; formal analysis, H.H.; investigation, M.I.; data curation, H.H.; writing—original draft preparation, M.I.; writing-review and editing, M.I.; visualization, M.R.; supervision, H.I.; project administration, A.I. All authors have read and agreed to the published version of the manuscript.

Funding: This research received no external funding.

Conflicts of Interest: The authors declare no conflict of interest.

\section{References}

1. Issa, M.; Ibrahim, H.; Lepage, R.; Ilinca, A. A Review and Comparison on Recent Optimization Methodologies for Diesel Engines and Diesel Power Generators. J. Power Energy Eng. 2019, 7, 31-56. [CrossRef]

2. German-Galkin, S.; Tarnapowicz, D.; Matuszak, Z.; Jaskiewicz, M. Optimization to Limit the Effects of Underloaded Generator Sets in Stand-Alone Hybrid Ship Grids. Energies 2020, 13, 708. [CrossRef]

3. Jabeck, B. The Impact of Generator Set Underloading. In Articles, Electric Power; Caterpillar Inc.: Deerfield, IL, USA, 2013; Available online: https://www.cat.com/en_IN/by-industry/electric-power/Articles/Whitepapers/the-impact-of-generator-setunderloading.html\#: \{\}:text=Detonation \%20will\%20decrease $\% 20$ the $\%$ 20life, and\%20behind\%20the\%20piston\%20rings (accessed on 29 July 2020).

4. Ibrahim, H.; Issa, M.; Lepage, R.; Ilinca, A.; Perron, J. Supercharging of Diesel Engine with Compressed Air: Experimental Investigation on Greenhouse Gases and Performance for a Hybrid Wind-Diesel System. Smart Grid Renew. Energy 2019, 10, 213-236. [CrossRef]

5. Wilson, J.; Calow, J. Cylinder bore polishing in automotive diesel engines-A progress report on a European study. In SAE Technical Paper; 1976; Available online: https://www.sae.org/publications/technical-papers/ content/760722/ (accessed on 18 October 2020).

6. Tarnapowicz, D. LoadAnalysisofaShipGeneratingSetsDuringtheManeuversoftheVessel. In Proceedings of the 59th International Conference of Machine Design Departments, Demanovska Dolina, Slovakia, 11-14 September 2018.

7. Wright, G. Fundamentals of Medium/Heavy Duty Diesel Engines; Jones \& Bartlett: Burlington, MA, USA, 2015; p. 234.

8. Kristenen, H.O. Energy Demand and Exhaust Gas Emissions of Marine Engines. In Project No. 2014-122: Mitigating and Reversing the Side-Effects of Environmental Legislation on Ro-Ro Shipping in Northern Europe Work Package 2.3, Report No. 03 2015; Psaraftis, H., Ed.; The Technical University of Denmark: Kopenhaga, Denmark, 2015; Available online: https://www.danishshipping.dk/ (accessed on 29 July 2020). 
9. ASCO Power Technologies. Adverse Effects of Low Load Operation on Diesel Generating Sets. Available online: https://www.ascopower.com/ca/en/download/document/LB-WP-ADVEFFCTLLODSLGENSETS/ (accessed on 1 August 2020).

10. Ayodele, T.R.; Ogunjuyigbe, A.S.O.; Akinola, O.A. N-Split Generator Model: An Approach to Reducing Fuel Consumption, LCC, CO2 Emission and Dump Energy in a Captive Power Environment. Sustain. Prod. Consum. 2017, 12, 193-205. [CrossRef]

11. Issa, M.; Ibrahim, H.; Ilinca, A.; Hayyani, M. A Review and Economic Analysis of Different Emission Reduction Techniques for Marine Diesel Engines. Open J. Mar. Sci. 2019, 9, 148-171. [CrossRef]

12. Tufte, E.D. Impacts of Low Load Operation of Modern Four-Stroke Diesel Engines in Generator Configuration. Master's Thesis, Institutt for Marin Teknikk, Trondheim, Norway, 2014.

13. Ibrahim, H.; Ilinca, A.; Perron, J. Solutions actuelles pour une meilleure gestion et integration de la ressource eolienne. CSME/SCGM Forum 2008 at Ottawa. Can. Soc. Mech. Eng. 2008, 1, 5-8.

14. ACEE. Association Canadienne de L'energie Eolienne. Available online: http://www.canwea.com (accessed on 18 October 2020).

15. Maisson, J.F. Wind power development in sub-arctic conditions with severe rime icing. In Proceedings of the Circumpolar Climate Change Summit and Exposition, Whitehorse, Yukon, 19-21 March 2001.

16. Available online: www.nunavutpower.com (accessed on 18 October 2020).

17. Reeves, B. Kotzebue electric association wind projects. In Proceedings of the NREL/AWEA 2002 Wind-Diesel Workshop, Anchorage, AK, USA, 30 November 2002.

18. Ibrahim, H.; Younes, R.; Ilinca, A.; Ramdenee, D.; Dimitrova, M.; Perron, J. Potential of a hybrid wind-diesel-CAES system for nordic remote Canadian areas. Energy Procedia 2011, 6, 795-804. [CrossRef]

19. Ibrahim, H.; Dimitrova, M.; Ilinca, A.; Perron, J. Etude et conception d'un systeme hybride eolien-diesel-stockage d'air comprime pour l'electrification d'une station de telecommunication isolee. Eur. J. Electr. Eng. 2009, 12, 701-731.

20. Ibrahim, H.; Ghandour, M.; Dimitrova, M.; Ilinca, A.; Perron, J. Integration of wind energy into electricity systems: Technical Challenges and actual Solutions. Energy Procedia 2011, 6, 815-824. [CrossRef]

21. Reid, R. Application de l'eolien en reseaux non relies. Liaison Energ.-Francoph 1997, 18. Available online: https://www.osti.gov/etdeweb/biblio/537526 (accessed on 18 October 2020).

22. Jean, Y.; Nouaili, A.; Viarouge, P.; Saulnier, B.; Reid, R. Developpement d'un systeme JEDHPSS representatif d 'un village typique des reseaux non relies. Rapp IREQ-94-169-C 1994, 94, 25-40.

23. Gagnon, R.; Nouaili, A.; Jean, Y.; Viarouge, P. Mise a jour des outils de modelisation et de simulation du Jumelage Eolien-Diesel a Haute Penetration Sans Stockage et redaction du devis de fabrication de la charge de lissage. Rapp IREQ-97-124-C 1997, 97, 103-121.

24. Issa, M.; Fiset, J.; Mobarra, M.; Ibrahim, H.; Ilinca, A. Optimizing the performance of a 500kW Diesel Generator: Impact of the Eo-Synchro concept on fuel consumption and greenhouse gases. Power Eng. 2018, 23, 22-31.

25. Available online: www.danvest.com (accessed on 18 October 2020).

26. Ilinca, A.; Chaumel, J.L. Implantation d'une centrale eolienne comme source d'energie d'appoint pour des stations de telecommunications. In Proceedings of the Colloque Int Sur L'energie Eolienne Les Sites Isolees, Iles de la Madeleine, QC, Canada, 3 September 2005; pp. 11-15.

27. Asco Power Technologies. Asco White Paper. Adverse Effects of Low Load Operation on Diesel Generating Sets. 2018. Available online: https://www.ascopower.com/ca/fr/download/document/LB-WPADVEFFCTLLODSLGENSETS/ (accessed on 2 August 2020).

28. Buhaug, Ø. Deposit Formation on Cylinder Liner Surfaces in Medium-Speed Engines; NTNU: Taipei, Taiwan, 2003.

29. Brooks, P. Limitations on low load operation for fixed speed engines. In Cummins Marine Bulletin; No.2.05.00-02/17/2005; MAB: Melbourne, Australia, 2005.

30. Steernberg, K.; Forget, S. Paper No.: 198 The effects of a chanigng oil industry on marine fuel quality and how new and old analytical techniques can be used to ensure predictable performance in marine diesel engines. In Proceedings of the CIMAC Congress Vienna, Vienna, Austria, 21-24 May 2007; Available online: https://www.yumpu.com/en/document/read/40637338/the-effects-of-a-changing-oil-industry-onmarine-fuel-quality-and-how- (accessed on 30 July 2020).

31. Onuki. Investigation of Engine Breakdown of Electric Propulsion in North European Sea; Mitsubishi Heavy Industries, Ltd.: Tokyo, Japan, 2007. 
32. Stachowiak, G.W.; Batchelor, A. Engineering Tribology, 4th ed.; Butterworth-Heinemann Ltd.: Oxford, UK, 2013.

33. Rakopoulos, C.D.; Giakoumis, E.G. Diesel Engine Transient Operation; Springer: Berlin/Heidelberg, Germany, 2009.

34. Caterpillar. Electric Power Applications, Engine \& Generator Sizing; Wiley-IEEE Press: Hoboken NJ, USA, 2008. [CrossRef]

35. Houben, D.-I.H.; Rottner, D.-I.B.M. Influence of Modern Diesel Cold Start Systems on the Cold Start, Warm-Up and Emissions of Diesel Engines. In BERU AG, Mörikestrasse 155; Citeseer: Ludwigsburg, Germany, 2008.

36. Rakopoulos, C.D. Influence of ambient temperature and humidity on the performance and emissions of nitric oxide and smoke of high speed diesel engines in the Athens/Greece region. Energy Convers. Manag. 1991, 31, 447-458. [CrossRef]

37. Schulz, C.; Sick, V. Tracer-LIF diagnostics: Quantitative measurement of fuel concentration, temperature and fuel/air ratio in practical combustion systems. Prog. Energy Combust. Sci. 2005, 31, 75-121. [CrossRef]

38. Rakopoulos, C.D.; Hountalas, D.T.; Zannis, T.C.; Levendis, Y.A. Operational and environmental evaluation of diesel engines burning oxygen-enriched intake air or oxygen-enriched fuels: A review. SAE Trans. 2004, $141,1723-1743$.

39. Abdullah, N.R.; Ismail, H.; Michael, Z.; Rahim, A.A.; Sharudin, H. Effects of air intake temperature on the fuel consumption and exhaust emissions of natural aspirated gasoline engine. J. Teknol. 2015, 76, 25-29. [CrossRef]

40. Issa, M.; Fiset, J.; Ibrahim, H.; Ilinca, A. Eco-Friendly Selection of Diesel Generator Based on Genset-Synchro Technology for Off-Grid Remote Area Application in the North of Quebec. Energy Power Eng. 2019, 11, 232-247. [CrossRef]

41. Jues, T. Modélisation et Simulation Des Gaz de Blow-By Dans un Décanteur Automobile. Ph.D. Thesis, École Nationale Supérieure d'Arts et Métiers, Paris, France, 2010.

42. Froelund, K.; Yilmaz, E. Impact of engine oil consumption on particulate emissions. In Proceedings of the ICAT International Conference on Automotive Technology, Istanbul, Turkey, 13-14 November 2004.

43. Randimbisoa, M.T. Formation de Gels et D'émulsions Dans le Circuit de Blow-By des Moteurs à Combustion Interne; Université Pierre et Marie Curie-Paris VI: Paris, France, 2011.

44. International Standard Atmosphere. ISO 2533; ISO: Geneva, Switzerland, 1975.

45. Hiroyasu, H.; Arai, M.; Tabata, M. Empirical Equations for the Sauter Mean Diameter of a Diesel Spray. In SAE Transactions; SAE Technical Paper 890464; JSTOR: New York, NY, USA, 1989. [CrossRef]

46. Kihm, K.D.; Terracina, D.P.; Payne, S.E.; Caton, J.A. Synchronised droplet size measurements for coal-water slurry sprays generated from a high-pressure diesel injection system. J. Inst. Energy 1994, 67, 2-9.

47. Zama, Y.; Ochiai, W.; Furuhata, T.; Arai, M. Experimental study on spray angle and velocity distribution of diesel spray under high ambient pressure conditions. At. Sprays 2011, 21, 989-1007. [CrossRef]

48. Lizhong, S.; Yungang, S.; Wensheng, Y.; Junding, X. Combustion Process of Diesel Engines at Regions with Different Altitude. SAE Technical Paper 950857, 1995. Available online: https://www.sae.org/publications/ technical-papers/content/950857/ (accessed on 18 October 2020).

49. Dec, J. A Conceptual Model of DI Diesel Combustion Based on Laser-Sheet Imaging. In SAE Technical Paper 970873; JSTOR: New York, NY, USA, 1997. [CrossRef]

50. Wu, H.; Nithyanandan, K.; Zhou, N.; Lee, T.H.; Chia-fon, F.L.; Zhang, C. Impacts of acetone on the spray combustion of Acetone-Butanol-Ethanol (ABE)-Diesel blends under low ambient temperature. Fuel 2015, 142, 109-116. [CrossRef]

51. Kan, Z.; Hu, Z.; Lou, D.; Tan, P.; Cao, Z.; Yang, Z. Effects of altitude on combustion and ignition characteristics of speed-up period during cold start in a diesel engine. Energy 2018, 150, 164-175. [CrossRef]

52. Wang, X.; Ge, Y.; Yu, L.; Feng, X. Effects of altitude on the thermal efficiency of a heavy-duty diesel engine. Energy 2013, 59, 543-548. [CrossRef]

53. Perez, P.L.; Boehman, A.L. Performance of a single-cylinder diesel engine using oxygen-enriched intake air at simulated high-altitude conditions. Aerosp. Sci. Technol. 2010, 14, 83-94. [CrossRef]

54. He, C.; Ge, Y.; Ma, C.; Tan, J.; Liu, Z.; Wang, C.; Yu, L.; Ding, Y. Emission characteristics of a heavy-duty diesel engine at simulated high altitudes. Sci. Total Environ. 2011, 409, 3138-3143. [CrossRef]

55. Clark, H.L. Naval Electrochemical Corrosion Reducer. U.S. Patent No. 5,052,962, 21 May 1990. 
56. Durand, W.F. Practical Marine Engineering. In BoD-Books on Demand; Academicpress GMbH: Bremen, Germany, 2015; Available online: https://books.google.com.hk/books?hl=zh-CN\&lr= $\& \mathrm{id}=$ CyQhBgAAQBAJ\&oi=fnd\&pg=PA1\&dq=Practical+Marine+Engineering. + In+BoD-Books+on+ Demand\&ots=Owf6oouSO9\&sig=Dxcssm3yjH_vrhFMA8YyAw8ni_E\&redir_esc=y\#v=onepage\&q= Practical\%20Marine\%20Engineering.\%20In\%20BoD-Books\%20on\%20Demand\&f=false (accessed on 18 October 2020).

57. Feng, Q.; Zhang, Y.Y. Anti-corroasion Design of Marine Diesel Engines. Intern. Combust. Engines 2007, 3 , 1481-1489.

58. Watson, G.O. Marine Electrical Practice; Elsevier: Amsterdam, The Netherlands, 2013.

59. Mobley, R.K. Root Cause Failure Analysis; Butterworth-Heinemann: Oxford, UK, 1999.

60. Albright, J.D.; Albright, D.R. Generator Field Winding Shorted Turns: Observed Conditions and Causes. In Proceedings of the EPRI International Conference, Orlando, FL, USA, 20 January 2003.

61. Bothwell, J. Monitoring Moisture in Hydrogen Cooled Generators. In Proceedings of the EPRI On-Line Monitoring and Condition Assessment Workshop, Nashville, TN, USA, 26 August 2003.

62. Kirn, M.; Grammer, W.; Kraemer, G.; Eule, M. Armature for High Speed Electric Motors Force-Ventilated Air Containing Abrasive Dust. U.S. Patent No. 5,352,948, 11 January 1993.

63. Culbert, I.M. A Review of Cleaning Methods for Motor Windings. In Proceedings of the 2008 IEEE Cement Industry Technical Conference, Miami, FL, USA, 18-22 May 2008. [CrossRef]

Publisher's Note: MDPI stays neutral with regard to jurisdictional claims in published maps and institutional affiliations.

(C) 2020 by the authors. Licensee MDPI, Basel, Switzerland. This article is an open access article distributed under the terms and conditions of the Creative Commons Attribution (CC BY) license (http://creativecommons.org/licenses/by/4.0/). 